\title{
Unravel Entrepreneurial Mindset in Indonesian Higher Education Institutions
}

\author{
Dorojatun Prihandono ${ }^{1}$, Sri Utami ${ }^{2}$ \\ ${ }^{1,2}$ Faculty of Economics, Universitas Negeri Semarang \\ ${ }^{1}$ Corresponding email: dprihandono@mail.unnes.ac.id
}

\begin{abstract}
The word of Entrepreneurial in higher education institution relates to characteristics of social system involving elements in universities such as departments, research centres, faculties and any collaboration with other parties. Entrepreneurial is a concept in which it is highly related to institution-building because institutions need to take risk in introducing new practices to innovate its activities. One of the main things a university can do to explore its entreprenurial and innovative potential is by conducting an assessment. One way to do this is by implementing HEInnovate self-assessment tool for higher educations institutions (HEIs). This paper aims to explore the current states of Universitas Negeri Semarang in entrepreneurial context. The self-assessment highlights a glimpses of current situation at the institution related to entrepreneurial activities based on eight areas; leadership and governance, organisational capacity, entrepreneurial teaching and learning, preparing and supporting entrepreneurs, digital transformation and capability knowledge exchange and collaboration, the internasionalised institution, and measuring impact. There were lecurers, students, and administrative leaders involved in applying this tool to assess the aforementionedareas. The result of this assessment will be used as a basis in creating action plans to support UNNES in the process of becoming better entrepreneurial university.
\end{abstract}

Keywords: HEInnovate Tools,Self-Assessment, Entrepreneurial University, Higher Education Institution

\section{Introduction}

Higher Education Institutions (HEI) or University has become a centre of developing innovations for many decades. Entrepreneurial mindset has become a pertinent factor in enhancing the ability of university to be more creative and innovative in many different areas (Ireland \& Sirmon, 2003). Furthermore, to cope with current global state, such as industry revolution 4.0 for instance, university has to be more innovative, not only to enhance its graduate's employability but strengthen its relationship with industries as well (Gordon \& Jack, 2010). More demanding global marketplace also has become an essential factor in how university obtain its graduates to fulfil the market (Kriewall \& Mekemson, 2010). Many universities all over the world have declared themselves as entrepreneurial universities or at least they have entrepreneurial thing in their vision and mission. According to Hannon (2013) it is more than that, the entrepreneurial university needs to adapt with dynamically changing environment. Furthermore, changes in global environment, including online technology, social mobility, contending nation states and geopolitics, demographics and of course economic burdens on governments to re-examine their investments in state funded services have all contributed to a highly ambiguous and changeable environment for higher education such as university (Markman et al., 2005; Gibb et al., 2012).

This study aims to explore current condition of entrepreneurial mindset among students, staffs and lecturers in Universitas Negeri Semarang specifically in economics faculty. Furthermore, this study can provide a clearer picture of the current entrepreneurial state in the university, this picture of how the students, staffs and lecturers think concerning entrepreneurial mindset will provide the university with future plan of actions that pertinent for Universitas Negeri Semarang to respond to dynamic changes of global environment.

\section{Literature Review}

Drucker (1985) emphasised that entrepreneurial individuals are people that are able to drive innovation, whereas innovation is enhanced by people who can think, behave and act in an entrepreneurial manner. In order to have a holistic understanding of entrepreneur, there are several definitions of entrepreneurship. The first is entrepreneurship itself can be defined as is self-employment through business ownership, which has significant elements of risk, control and reward. (This definition of entrepreneurship was coined by John Hughes, the Coleman Foundation's 
Chairman Emeritus cited in Kriewall \& Mekemson, 2010, p.8). The other definition of entrepreneurship that can be adopted by university in academic context, where Gibb and Hannon (2006, p.10) emphasised that entrepreneurialism is a development in form of individual behaviors, skills and attitudes as characterised by entrepreneur, besides that same characteristics can also be applied to intrapreneur, social entrepreneur, technopeneur and across many other contexts. Those definitions of entrepreneurship should be embedded into so called 'entrepreneurial university', in other words, it is not only as jargon, but it has to be a way of thinking of how the university runs their resources and capabilities. It is quite pertinent, due to the drastic changes in global environment and the university need to adapt and respond; furthermore, it also need to answer several questions such as what to do? how to do it? And who you do it with? (Kriewall \& Mekemson, 2010; D'este \& Perkman, 2011; Hannon, 2013).

The university degree is regarded as no longer a ticket for life-long employability but simply an entry ticket into a real work world. One key component of this view is encourgement of students to consider a career in entrepreneurship, with an emphasis upon managing independence and the capacity to develop growth ventures which has 'highimpact' factors (Gibb \& Hannon, 2006). There is a stage when a university need to change its way of thinking, this transition to become the entrepreneurial university also encompasses the evolution from individual to collective and organisational entrepreneurship (Etzkowitz et al., 2008). Rae et al. (2012) emphasised that university or HEI has a significant part in stimulating student and graduate entrepreneurship, and also provides education and encouragement for present and future entrepreneurs.

Entrepreneurship in some way struggled to gain academic legitimacy at an ethical, pedagogical and theoretical level, with the quality and focus of research being constraints (Lewis, 2011). Embedding entrepreneurship in a HEI or university need a strategic approach including teaching methods, pedagogical approach and lecturers/staffs who has entrepreneurship thinking as well (Kriewall \& Mekemson, 2010; Blenker 2011). Based on that, there are challenges in developing entrepreneurial HEI or university. Universities' managers need to create environments conducive enough for developing entrepreneurial mindsets and behaviors, and it is pertinent that HEIs or universities are able themselves reflect and behave in a more entrepreneurial strategic mode for addressing multiple pressures they face to adapt and respond to overly changing global environment (Gibb et al., 2012). Furthermore, Gibb et al. (2012); Bramwell and Wolfe (2008) emphasised that there are several factors that force HEIs or university become entrepreneurial, such as: Firstly, the government's regulations that can be interpreted as wanting more from less; it can be in form of several ideas: demanding solutions to current economic issues; demanding new sources of employment to counter losses in corporate and public sectors; and seeking solutions to contending growing unemployment; Secondly is derived from businesses, the businesses or employers wanting more from the graduates, not only theoretical knowledge and basic skills but also innovation and ideas to enhance the businesses' competitiveness; Thirdly, Students wanting better education that has value for money, so that they can pay their debts during their education after they graduate by possessing good employability ; Fourthly, HEIs or universities being perceived as leaders of research and development in obtaining innovations and technological formulas and also HEIs or universities are seen as driving forces for economic growth; Fifthly, huge expectations from the parents, they wanting the best opportunities for their children to cope with uncertain future. Kweick (2012) argues that HEIs or universities can use incremental, radical and accidental pathways. The pathways of changes can be incremental where essential principles remain within HEIs or universities, there will be a management processes transformation introduced as part of a longerterm strategic plan. The next pathway is the radical approach, a complete renewal in organisational structures and governance, in strategic, for example: mergers and acquisitions are radical change for HEIs and universities. The last pathway is accidental, change happens to the HEIs or universities; it is accidental and can reflect a win-win cooperation with their stakeholder.

Academic revolution enables HEIs or universities to change (Shattock, 2009; Kwick, 
2012); these scholars emphasise that an HEI should be able to align its resources to respond and adapt the challenges and pressures; and able to provide a supportive environment and activities within institution to develop entrepreneurial mindset and behaviour. The need for embedding the entrepreneurial mindset in the HEIs or universities is as important in a company which must withstands global competitiveness in 21st century (Bryan \& Joyce, 2007). However, the greatest challenge remains in 'how' HEIs or universities become entrepreneurial institutions and how they develop supportive and effective environments for developing entrepreneurial capacities in their staff and students (Kuratko, 2005; Hannon, 2012). The challenges in understanding 'why' and 'what' of entrepreneurial university, more and more institutions recognise both its importance for a 21st Century higher education institution and the need to enhance their organisational adaptability and flexibility (Bryan and Joyce, 2009; Hannon, 2012).

\section{Methodology}

The survey was commenced in Universitas Negeri Semarang, it consists of 64 respondents from all lecturers, professors, students, administrative leaders, dean/faculty leaders; researcher and experts from all units in the university.

The specific method is applied to explore the current entrepreneurial state of the institutions, this methodology is called HEinnovate assessment tool (EC OECD, 2018; Judd \& Laing, 2017). The methodology is derived from the European Commission (EC)Organisation for Economics and Cooperation Development (OECD). HEInnovate is a selfassessment tool for HEI or universities, polytechnics or colleges who wish to explore their innovative potential. It guides the HEIs and any other form of education instituions through a process of identification, prioritisation and action planning in eight key areas (EC OECD, 2018). HEInnovate also diagnoses areas of strengths and weaknesses and enable individuals in the HEIs to discuss and argue on entrepreneurial / innovative nature of the institution, besides that it allows the HEIs or universities to compare and contrast evolution throughout time (EC OECD, 2018).
The eight keys areas that can be explored using the HEInnovate tools are (EC OECD, 2018):

1. Leadership and Governance

2. Organisational Capacity: Funding, People and Incentives

3. Entrepreneurial Teaching and Learning

4. Preparing and Supporting Entrepreneurs

5. Digital Transformation and Capability

6. Knowledge Exchange and Collaboration

7. The Internationalised Institution

8. Measuring Impact

\section{Results and discussion}

\section{a.Leadership and Governance}

"There is a commitment at a high level to implementing the entrepreneurial agenda" means that mostly participants are optimistic that UNNES has a high commitment to implement the entrepreneurial agenda. Meanwhile, the statement of "There is a model in place for coordinating and integrating entrepreneurial activities across the HEI" has the lowest score of 2. It indicates that UNNES has no model to accomodate the entrepreneurial activities across existing faculties or units. Then, the clear gap of participants' view is in the statement of "The HEI is a driving force for entrepreneurship and innovation in regional, social, and community development". The huge gap happens between the category of students and other.

Table 1. Overview of the statements

\begin{tabular}{|c|c|c|}
\hline Type & Statement & Score \\
\hline $\begin{array}{l}\text { Statement } \\
\text { with the } \\
\text { highest } \\
\text { score }\end{array}$ & $\begin{array}{l}\text { There is a } \\
\text { commitment at a } \\
\text { high level to } \\
\text { implementing the } \\
\text { entrepreneurial } \\
\text { agenda }\end{array}$ & 4.5 \\
\hline $\begin{array}{l}\text { Statement } \\
\text { (s) with } \\
\text { the lowest } \\
\text { score }\end{array}$ & $\begin{array}{l}\text { There is a model in } \\
\text { place for } \\
\text { coordinating and } \\
\text { integrating } \\
\text { entrepreneurial } \\
\text { activities across the } \\
\text { HEI }\end{array}$ & 2 \\
\hline $\begin{array}{l}\text { Largest } \\
\text { different } \\
\text { across the } \\
\text { views } \\
\text { (variance) }\end{array}$ & $\begin{array}{l}\text { The HEI is a driving } \\
\text { force for } \\
\text { entrepreneurship } \\
\text { and innovation in } \\
\text { regional, social, and } \\
\text { community } \\
\text { development. }\end{array}$ & - \\
\hline
\end{tabular}




\section{b. Organisational Capacity, Funding, People, and Incentives}

The result of the Organisational Capacity, Funding, People, and Incentives - the second dimension is presented in Table 2. The highest score reaches 4.5. It means that most participants agree that there is a sources of funding and investment supporting entrepreneurial objectives in UNNES. However, they confirm that there is a lack of incentives and rewards for staff supporting the activities to reach such objectives (Table 2). The quite significant gap is on "The HEI invests in staff development to support its entrepeneurial agenda" view coming from students, professor/teacher, administrative leader, Dean/head of school/faculty, as well as not provided and other category of participant.

Table 2. Overview of the statements (area 2)

\begin{tabular}{|c|c|c|}
\hline Type & Statement & Score \\
\hline $\begin{array}{l}\text { Statement } \\
\text { with the } \\
\text { highest } \\
\text { score }\end{array}$ & $\begin{array}{l}\text { Entrepreneurial } \\
\text { objectives are } \\
\text { supported by a } \\
\text { wide range of } \\
\text { sustainable } \\
\text { funding and } \\
\text { investment sources }\end{array}$ & 4.5 \\
\hline $\begin{array}{l}\text { Statement } \\
\text { (s) with } \\
\text { the lowest } \\
\text { score }\end{array}$ & $\begin{array}{l}\text { Incentives and } \\
\text { rewards are given } \\
\text { to staff who } \\
\text { actively support } \\
\text { the entrepreneurial } \\
\text { agenda }\end{array}$ & 1 \\
\hline $\begin{array}{l}\text { Largest } \\
\text { different } \\
\text { across the } \\
\text { views } \\
\text { (variance) }\end{array}$ & $\begin{array}{l}\text { The HEI invests in } \\
\text { staff development } \\
\text { to support its } \\
\text { entrepeneurial } \\
\text { agenda }\end{array}$ & - \\
\hline
\end{tabular}

\section{c.Entrepreneurial Teaching and Learning}

The next dimension is Entrepreneurial teaching and learning. Its survey result is presented in Table 3 below. Most participants agree that UNNES already provides many kinds opportunities in formal learning to develop entrepreneurial mindset and skills. It is seen its highest score (4.04) in the statement of "The HEI provides diverse formal learning opportunities to develop entrepreneurial mindsets and skills". However, they are less optimistic that UNNES already integrates the entreprenuership-related research in the teaching and learning process, offers informal learning opportunities and experiences, and also co-designs and delivers in cooperation with external partners. The last statement also becomes the huge gaps among the participants of the survey.

Table 3. Overview of the statements

\begin{tabular}{|c|c|c|}
\hline Type & Statement & Score \\
\hline $\begin{array}{l}\text { Statement } \\
\text { with the } \\
\text { highest } \\
\text { score }\end{array}$ & $\begin{array}{l}\text { The HEI provides } \\
\text { diverse formal learning } \\
\text { opportunities to develop } \\
\text { entrepreneurial } \\
\text { mindsets and skills }\end{array}$ & 4.04 \\
\hline $\begin{array}{l}\text { Statement } \\
\text { (s) with the } \\
\text { lowest score }\end{array}$ & $\begin{array}{l}\text { Result of } \\
\text { entrepreneurship } \\
\text { research are integrated } \\
\text { into the entrepreneurial } \\
\text { education offer. } \\
\text { The HEI provides } \\
\text { diverse informal } \\
\text { learning opportunities } \\
\text { and experiences to } \\
\text { stimulate } \\
\text { development the } \\
\text { entrepreneurial } \\
\text { mindsets and skills. } \\
\text { The HEI co-designs and } \\
\text { delivers the curriculum } \\
\text { with external } \\
\text { stakeholders }\end{array}$ & 2 \\
\hline $\begin{array}{l}\text { Largest } \\
\text { different } \\
\text { across the } \\
\text { views } \\
\text { (variance) }\end{array}$ & $\begin{array}{l}\text { The HEI co-designs and } \\
\text { delivers the curriculum } \\
\text { with external } \\
\text { stakeholders }\end{array}$ & - \\
\hline
\end{tabular}

\section{d.Preparing and Supporting Entrepreneurs}

The statements having the score of 4 - as the highest, involve the HEI increases the awareness of the value of entrepreneurship and stimulates the entrepreneurial intentions of students, graduates and staff to start-up a business or venture; the HEI offers or facilitates access to business incubation and the HEI supports its students, graduates, and staff to move from idea generation to business creation. While the lowest is related to training offered to students, graduates, and staff in starting, running, and growing a business. Furthermore, the participants of the survey have a gap in viewing whether UNNES provide mentoring for everyone from experienced people in their field or industry. 
Table 4. Overview of the statements

\begin{tabular}{|c|c|c|}
\hline Type & Statement & Score \\
\hline $\begin{array}{l}\text { Statement } \\
\text { (s) with the } \\
\text { highest } \\
\text { score }\end{array}$ & $\begin{array}{l}\text { The HEI increases the } \\
\text { awareness of the value } \\
\text { of entrepreneurship and } \\
\text { stimulates the } \\
\text { entrepreneurial } \\
\text { intentions of students, } \\
\text { graduates and staff to } \\
\text { start-up a business or } \\
\text { venture. } \\
\text { The HEI offers or } \\
\text { facilitates access to } \\
\text { business incubation. } \\
\text { The HEI supports its } \\
\text { students, graduates, and } \\
\text { staff to move from idea } \\
\text { generation to business } \\
\text { creation. }\end{array}$ & 4 \\
\hline $\begin{array}{l}\text { Statement } \\
\text { (s) with the } \\
\text { lowest score }\end{array}$ & $\begin{array}{l}\text { Training is offered to } \\
\text { assist students, } \\
\text { graduates, and staff in } \\
\text { starting, running, and } \\
\text { growing a business. }\end{array}$ & 2 \\
\hline $\begin{array}{l}\text { Largest } \\
\text { different } \\
\text { across the } \\
\text { views } \\
\text { (variance) }\end{array}$ & $\begin{array}{l}\text { Mentoring and other } \\
\text { forms of personal } \\
\text { development are } \\
\text { offered by experienced } \\
\text { individuals from } \\
\text { academia or industry }\end{array}$ & - \\
\hline
\end{tabular}

\section{e.Digital Transformation and Capability}

Table 5. Overview of statements

\begin{tabular}{|c|c|c|}
\hline Type & Statement & Score \\
\hline $\begin{array}{l}\text { Statement } \\
\text { (s) with the } \\
\text { highest } \\
\text { score }\end{array}$ & $\begin{array}{l}\text { The HEI fosters a digital } \\
\text { culture as a mean for } \\
\text { innovation and } \\
\text { entrepreneurship. } \\
\text { The HEI has a dynamic } \\
\text { digital presence } \\
\text { supporting all its } \\
\text { activities. }\end{array}$ & 4 \\
\hline $\begin{array}{l}\text { Statement } \\
\text { (s) with the } \\
\text { lowest score }\end{array}$ & $\begin{array}{l}\text { Open science and } \\
\text { innovation practices are } \\
\text { widespread across the } \\
\text { HEI. } \\
\text { The HEI is committed } \\
\text { to digital teaching, } \\
\text { learning, and } \\
\text { assessment practices. }\end{array}$ & 1 \\
\hline $\begin{array}{l}\text { Largest } \\
\text { different } \\
\text { across the } \\
\text { views } \\
\text { (variance) }\end{array}$ & $\begin{array}{l}\text { Open science and } \\
\text { innovation practices are } \\
\text { widespread across the } \\
\text { HEI. }\end{array}$ & - \\
\hline
\end{tabular}

The fifth is related to digital transformation and capability (area/dimension 5). Participants seem to agree that UNNES embraces the digitalisation for supporting innovation and activities (score 4). Then, participants are mostly pessimistic about the existing of open science and innovation practices to openly widespread across units in UNNES, and commitment of making use of digitalisation in the teaching and learning process, as well as the assessment (score 1). The widespread of the innovation practices also has various view from participants.

\section{f.Knowledge Exchange and Collaboration}

Dimension 6- knowledge exhange and collaboration survey result is presented in Table 6. They indicate that participants of the survey agree that UNNES already integrates research, education, and industry (wider community) activities to exploit new knowledge (Score 4.5). However, they do not yet see that UNNES already provides opportunities for staff and students to take part in innovative activities with business/ the external environment. The clear gap of views among participant is whether UNNES HEI has strong links with incubators, science park and other external initiatives.

Table 6. Knowledge Exchange and Collaboration

\begin{tabular}{|c|c|c|}
\hline Type & Statement & Score \\
\hline $\begin{array}{l}\text { Statement } \\
\text { (s) with the } \\
\text { highest } \\
\text { score }\end{array}$ & $\begin{array}{l}\text { The HEI integrates } \\
\text { research, education, } \\
\text { and industry (wider } \\
\text { community) activities } \\
\text { to exploit new } \\
\text { knowledge }\end{array}$ & 4.5 \\
\hline $\begin{array}{l}\text { Statement } \\
\text { (s) with the } \\
\text { lowest score }\end{array}$ & $\begin{array}{l}\text { The HEI provides } \\
\text { opportunities for staff } \\
\text { and students to take } \\
\text { part in innovative } \\
\text { activities with business/ } \\
\text { the external } \\
\text { environment }\end{array}$ & 1 \\
\hline $\begin{array}{l}\text { Largest } \\
\text { different } \\
\text { across the } \\
\text { views } \\
\text { (variance) }\end{array}$ & $\begin{array}{l}\text { The HEI has strong } \\
\text { links with incubators, } \\
\text { science park and other } \\
\text { external initiatives. }\end{array}$ & - \\
\hline
\end{tabular}

\section{g. The Internasionalised Institution}

The highest score is 5 on the statement of "The HEI explicitly supports the international mobility of its staff and students" which means that participants confirm that UNNES already supports the internationalisation. The support is seen through the available opportunities for 
staff and students to involve in international mobility activities. However, the participants are doubt whether UNNES uses international dimension as an approach for researches and whether it is reflected in teaching (score 5inTable 7).

Table 7. Overview of statements

\begin{tabular}{|c|c|c|}
\hline Type & Statement & Score \\
\hline $\begin{array}{l}\text { Statement } \\
\text { (s) with the } \\
\text { highest } \\
\text { score }\end{array}$ & $\begin{array}{l}\text { The HEI explicitly } \\
\text { supports the } \\
\text { international mobility } \\
\text { of its staff and } \\
\text { students. }\end{array}$ & 5 \\
\hline $\begin{array}{l}\text { Statement } \\
\text { (s) with the } \\
\text { lowest } \\
\text { score }\end{array}$ & $\begin{array}{l}\text { The international } \\
\text { dimension is reflected } \\
\text { in the HEI's approach } \\
\text { and to research. } \\
\text { International } \\
\text { perspectives are } \\
\text { reflected in the HEI's } \\
\text { approach to teaching }\end{array}$ & 2 \\
\hline $\begin{array}{l}\text { Largest } \\
\text { different } \\
\text { across the } \\
\text { views } \\
\text { (variance) }\end{array}$ & $\begin{array}{l}\text { The HEI explicitly } \\
\text { supports the } \\
\text { international mobility } \\
\text { of its staff and } \\
\text { students. }\end{array}$ & - \\
\hline
\end{tabular}

\section{h. Measuring Impact}

The participants are optimistic that UNNES has regularly assessed the impact of entrepreneurial activities (score 4), while it does not necesarily reflect whether available personnels and resources already support them (score 2). The gap shows that they doubt if UNNES has regular assessment to see the impact of the support given to start-up.

Table 8. Overview of statements (8 Dimensions)

\begin{tabular}{|c|c|c|}
\hline Type & Statement & Score \\
\hline $\begin{array}{l}\text { Statement } \\
\text { (s) with the } \\
\text { highest } \\
\text { score }\end{array}$ & $\begin{array}{l}\text { HEI regularly } \\
\text { assesses the impact } \\
\text { of its entrepreneurial } \\
\text { agenda. }\end{array}$ & 4 \\
\hline $\begin{array}{l}\text { Statement } \\
\text { (s) with the } \\
\text { lowest } \\
\text { score }\end{array}$ & $\begin{array}{l}\text { The HEI regularly } \\
\text { assesses how its } \\
\text { personnel } \\
\text { resources support its } \\
\text { entrepreneurial } \\
\text { agenda. }\end{array}$ & 2 \\
\hline $\begin{array}{l}\text { Largest } \\
\text { different } \\
\text { across the } \\
\text { views } \\
\text { (variance) }\end{array}$ & $\begin{array}{l}\text { The HEI regularly } \\
\text { assesses the impact } \\
\text { of start-up support }\end{array}$ & - \\
\hline
\end{tabular}

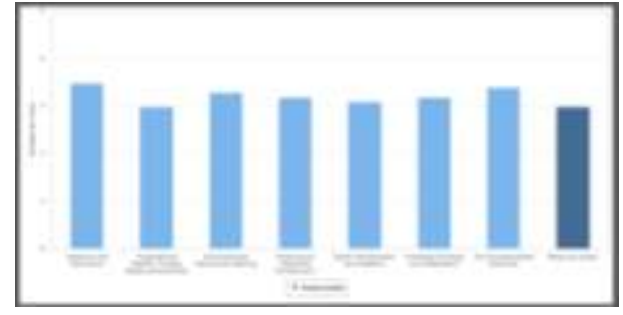

Figure 1: Group self-assessment result

The group self-assessment result is presented in Figure 1. On average, participants consider two dimensions are important to improve. They are (1) organisational capacity: funding, people, and incentives; and (2) measuring impact. The participants are optimistic that capacity of the organisation in UNNES is still less (score 3). As previously discussed (table 2), incentives and rewards are not fully available or are likely less for active staffs involved in supporting entrepreneurial activities in UNNES. The other one-the dimension of measuring impact, is also seminal to improve because the assessment of personnel and resources already support the existing entrepreneurial agenda in university.

\section{Conclusion}

UNNES has potential becoming better entrepreneurial and innovative higher education. The discussion above has identified current states of UNNES as an entrepreneurial university. For example, It can be seen from the survey result that participants agree that UNNES already has a commitment at a high level to implement the entrepreneurial agenda, sustainable funding and investment sources to support the activities, and learning opportunities for students and staff to acquire and develop entrepreneurial mindsets and skills. Furthermore, this university also indicates its awareness of the value of entrepreneurship and stimulates the entrepreneurial intentions of students, graduates and staff to start-up a business or venture. It also offers students to access business incubation facilities, and supports the ideas to business creation. In addition, UNNES fosters digital atmosphere to improve innovation.

Nevertheless, UNNES has other areas to improve in which most importantly related to organisational capacity involving the provision of funding, people, and incentives or rewards. Besides, it is expected that institution is aware 
of the impact measurement to see its progress in developing entrepreneurial activities. For instance, measuring the impact of resouces used to support the activity as well as the persons involved.

\section{References}

Blenker, P., Korsgaard, S., Neergaard, H., \& Thrane, C. (2011). The questions we care about: paradigms and progression in entrepreneurship education. Industry and Higher Education, 25(6), 417-427.

Bramwell, A., \& Wolfe, D. A. (2008). Universities and regional economic development: The entrepreneurial University of Waterloo. Research policy, 37(8), 1175-1187.

Bryan, L. L., \& Joyce, C. I. (2007). Better strategy through organizational design. McKinsey Quarterly, 2(07), 21-29.

D'este, P., \& Perkmann, M. (2011). Why do academics engage with industry? The entrepreneurial university and individual motivations. The Journal of Technology Transfer, 36(3), 316-339.

Drucker, P. (1985) Innovation and Entrepreneurship Principles and Practice. Harper\& Row, New York.

EC OECD. (2018). HEInnovate: Is your Higher Education Institution promoting the development of an entrepreneurial culture? Available at: https://heinnovate.eu/

Etzkowitz, H., Ranga, M., Benner, M., Guaranys, L., Maculan, A. M., \& Kneller, R. (2008). Pathways to the entrepreneurial university: towards a global convergence. Science and Public Policy, 35(9), 681-695.

Gibb, A., \& Hannon, P. (2006). Towards the entrepreneurial university. International Journal of Entrepreneurship Education, 4(1), 73-110.

Gibb, A., Haskins, G., \& Robertson, I. (2012). Leading the entrepreneurial university: Meeting the entrepreneurial development needs of higher education institutions. In Universities in change (pp. 9-45). Springer, New York, NY.

Gordon, I., \& Jack, S. (2010). HEI engagement with SMEs: developing social capital. International Journal of Entrepreneurial Behavior \& Research, 16(6), 517-539.
Hannon, P. D. (2013). Why is the entrepreneurial university important?. Journal of Innovation Management, 1(2), 10-17.

Ireland, R. D., Hitt, M. A., \& Sirmon, D. G. (2003). A model of strategic entrepreneurship: The construct and its dimensions. Journal of management, 29(6), 963-989.

Judd, P. M., \& Laing, S. (2017). Innovation and Enterprise Strategy.

Kriewall, T. J., \& Mekemson, K. (2010). Instilling the entrepreneurial mindset into engineering undergraduates. The journal of engineering entrepreneurship, 1(1), 5-19.

Kuratko, D. F. (2005). The emergence of entrepreneurship education: Development, trends, and challenges. Entrepreneurship theory and practice, 29(5), 577-597.

Kweick, M. (2012). Knowledge Production in European Universities. Higher Education Research and Policy-3, Peter Lang Edition.

Lewis, H. (2011). A model of entrepreneurial capability based on a holistic review of the literature from three academic domains. Industry and Higher Education, 25(6), 429-440.

Markman, G. D., Phan, P. H., Balkin, D. B., \& Gianiodis, P. T. (2005). Entrepreneurship and university-based technology transfer. Journal of business venturing, 20(2), 241-263.

Rae, D., Martin, L., Antcliff, V., \& Hannon, P. (2012). Enterprise and entrepreneurship in English higher education: 2010 and beyond. Journal of Small Business and Enterprise Development, 19(3), 380-401.

Shattock, M. (2009). Entrepreneurialism and organizational change in higher education. Entrepreneurialism in universities and the knowledge economy: Diversification and organizational change in European higher education, 1-8.

Thorp, H., \& Goldstein, B. (2010). Engines of Innovation: The Entrepreneurial University in the Twenty-First Century. Chapel Hill: The University of North Carolina Press. 